\title{
Stages of tectonothermal history of the Taimyr - Severnaya Zemlya orogen during oblique collision in the Carboniferous-Permian
}

\author{
A.E. VERNIKOVSKAYA ${ }^{1,2}$, V.A. VERNIKOVSKY ${ }^{1,2}$, \\ N.YU. MATUSHKIN ${ }^{1,2}$, V.F. PROSKURNIN ${ }^{3}$, \\ O.P. POLYANSKY ${ }^{4}$, YU.M. LAEVSKY ${ }^{5}$, A.V. TRAVIN ${ }^{4}$
}

${ }^{1}$ A.A. Trofimuk Institute of Petroleum Geology and Geophysics SB RAS, Novosibirsk, Russia, VernikovskayaAE@ipgg.sbras.ru

${ }^{2}$ Novosibirsk State University, Novosibirsk, Russia

${ }^{3}$ A.P. Karpinsky Russian Geological Research Institute, St. Petersburg, Russia

${ }^{4}$ V.S. Sobolev Institute of Geology and Mineralogy, SB RAS, Novosibirsk, Russia

${ }^{5}$ Institute of Computational Mathematics and Mathematical Geophysics SB RAS, Novosibirsk, Russia

Our study of the thermal history of the Taimyr Severnaya Zemlya (Kara) orogen was performed using structural, tectonic, geochronological data and numerical modelling. This included the building of a 3D numerical model of the thermal history of the oblique collision between the Kara microcontinent and the Siberian paleocontinent in the Palaeozoic, taking into account the 3D drift kinematics of the plates and the evolution of the temperature field of the collision process.

The effect of oblique collision is relected in the movement of a high-temperature anomaly along the strike of the orogen from west to east to a distance of $700 \mathrm{~km}$ together with granite formation areas and gradual decrease in age of the granites (U-Pb data for zircons). Syncollisional granites formed in the intervals 309-303 Ma and 287-282 Ma, while postcollisonal granites - in the interval 264-252 Ma.

The cooling of the Taimyr - Severnaya Zemlya orogen confirmed based on ${ }^{40} \mathrm{Ar} /{ }^{39} \mathrm{Ar}$ data for amphibole, feldspar and biotite in postcollisional granites (253-252 Ma and 247$245 \mathrm{Ma}$ ) coincides with the transformation of the geodynamic environment from convergent to divergent due to tectonic activity of the Siberian superplume.

This study was supported by the Russian Science Foundation (project no. 19-17-00091). 